\title{
Status Kepemilikan Hak Atas Tanah Adat Marga dalam Kebijakan Penataan Aset Reforma Agraria Di Kabupaten Maluku Tenggara
}

\author{
Ronald Saija $^{1 *}$, Fransiscus Xaverius Roger Vincen Letsoin ${ }^{2}$, Rory Jeff Akyuwen ${ }^{3}$, \\ Pieter Radjawane ${ }^{4}$. \\ 1,2,3,4 Fakultas Hukum Universitas Pattimura, Ambon, Indonesia \\ *E-mail: ronaldreagensaija@gmail.com
}

\begin{abstract}
Promulgation of Law Number 5 of 1960, brought its own consequences in terms of regulation of agrarian resources, including earth, water, space and natural resources contained therein. The ideals of the law in the realization of the objectives of the national agrarian law are realized in the form of the Agrarian Reform policy which is one of the ideals in the administration of President Joko Widodo. This policy was stated in the Decree of the People's Consultative Assembly of the Republic of Indonesia Number IX / MPR / 2001 concerning Agrarian Reform and Natural Resource Management and followed up with the issuance of Presidential Regulation Number 86 of 2018 concerning Agrarian Reform. The Presidential Regulation regulates the determination of assets in the legalization of agrarian reform land object certificates. However, the problem is that it is feared that disputes and agrarian conflicts will arise in the right of recognition of the existence of communal rights for indigenous and tribal peoples explicitly mentioned in Ministerial Regulation ATR / Ka.BPN Number 10 of 2016, which seems to be no longer recognized by indigenous peoples in Indonesia. This paper is a legal research that uses the method of the statutory approach and conceptual approach that examines the recognition and use of customary land by using the norms contained in legislation. The results of this paper are directed to be able to provide clarity of legalization of customary community land as well as communal rights of indigenous and tribal peoples related to the issuance of Presidential Regulation Number 86 of 2018 which does not expressly state the position of indigenous peoples as the subject of policy arrangement on Agrarian Reform assets, so that the rights owned by marga indigenous and tribal peoples can be fought for.
\end{abstract}

Keywords: Communal Rights; Asset Arrangement; Recognition; Agrarian Reform.

\section{A. PENDAHULUAN}

Hal yang mendasar dalam permasalahan pertanahan di Indonesia adalah lemahnya pengakuan dan perlindungan hukum terkait keberadaan masyarakat hukum adat marga. Konflik dalam penggunaan tanah antar berbagai sektor pembangunan karena bertambahnya jumlah penduduk, kelangkaan tanah dan kemunduran kualitasnya yang 
menyebabkan kemiskinan, sempitnya lapangan kerja dan akses yang tidak seimbang di dalam perolehan pemanfaatan tanahnya dan semakin terdesaknya hak-hak masyarakat hukum adat. ${ }^{1}$

Undang-Undang Nomor 5 Tahun 1960 tentang Pokok-Pokok Agraria menjelaskan bahwa kepemilikan masyarakat adat terhadap tanah ulayat sudah ada sebelum Indonesia merdeka. Untuk itu negara wajib memberikan perlindungan terhadap masyarakat adat sepanjang masih diakui, masih hidup, ada institusi dan masyarakat dan lembaga yang menaungi mereka untuk mengelola atau mengusahakan tanah yang dimiliki.

Fakta hukum saat itu sangat nyata terlihat adanya ketidakadilan, terdapat tuan-tuan tanah yang menguasai tanah yang sangat luas namun tidak mampu menggarapnya. Di lain pihak ada petani namun hanya sebagai penggarap, petani tidak memiliki tanah dan hanya menjadi buruh tani. Sebaliknya tuan-tuan tanah memperoleh manfaat yang melimpah dari tanah-tanah yang dikuasainya serta dikerjakan dan dikelola oleh petani-petani penggarap (buruh tani). Ketimpangan kepemilikan tanah dan ketidakadilan atas akses terhadap tanah oleh para petani menimbulkan pikiran yang menuntut rasa keadilan, karenanya melahirkan gerakan-gerakan untuk mengubah tatanan hokum baru yang lebih berkeadilan dan lebih berpihak kepada rakyat kecil, kaum tani serta para buruh. Oleh karena itu, lahirlah reforma agraria yang pada prinsipnya tanah untuk tani dan keadilan untuk semua, satu sistem hukum yang adil untuk semua rakyat.

Tanah merupakan kebutuhan, setiap manusia selalu berusaha untuk memilikinya, walaupun dalam kenyataannya ada juga yang tidak pernah memiliki tanah. Kebutuhan tanah bersifat pokok karena tanah mempunyai kedudukan tinggi bagi kehidupan manusia, yakni sebagai tempat manusia dilahirkan, dibesarkan, membangun kehidupannya sebagai tempat tinggal, sumber nafkah dan juga dibutuhkan jika nanti meninggal dunia. Dengan berkembangnya jumlah penduduk di Indonesia, kebutuhan tanah pun semakin meningkat dan hal tersebut mengakibatkan semakin luas tanah yang dikuasai. Keadaan tersebut melahirkan hak komunal dari seluruh anggota kelompok. Dalam perkembangan berikutnya, karena kebutuhan tanah terus meningkat sementara tanah semakin terbatas, dan memunculkan semakin kuatnya hak perorangan dibarengi semakin menipisnya hak komunal. $^{2}$

Pengakuan hukum adat sebagaimana disebutkan dalam UUPA, pada hakikatnya tidak jelas apakah hukum adat itu, hukum adat yang bagaimana dan berlakunya hukum adat tersebut. UUPA tidak memberikan penjelasan lebih lanjut mengenai hal ini, ketidakjelasan tersebut menunjukkan bahwa para pembentuk Undang-Undang sebenarnya bimbang dan ragu terutama tentang hukum adat mana yang diberlakukan. Di samping itu juga penjajahan dengan sistem positivisme hukum turut mewarnai sistem hukum Indonesia yang berpengaruh kuat pada saat itu.

Sampai saat ini, peraturan perundang-undangan masih sebatas pengakuan berupa pengakuan dan penghormatan hak ulayat masyarakat tersebut (pengakuan dengan pembatasan) yang semuanya dilakukan dengan tujuan untuk memberikan perlindungan hukum terhadap hak ulayat, tetapi menjadi tidak jelas dan menimbulkan penafsiran yang tidak memadai dengan tujuannya, bahkan sering meniadakan dan merugikan hak masyarakat hukum adat. Pengakuan secara formal diakui dalam Undang-Undang tetapi implementasinya sangatlah minim, sehingga tetap saja tidak ada perlindungan hukum, karena kalau terjadi suatu konflik baik antara pemerintah dengan masyarakat hukum adat

\footnotetext{
${ }^{1}$ Maria S.W. Sumardjono. (2001), Kebijakan Pertanahaan Antara Regulasi dan Implementasi, Jakarta: Kompas, h. 45.

2 Sembiring, Rosnidar. (2017), Hukum Pertanahan Adat, Depok: Rajagrafindo Persada, h..3
} 
atau antara pengusaha dengan masyarakat, ujung-ujungnya kenyataan pahit diterima oleh masyarakat hukum adat, karena tidak adanya keberpihakan dan sering meniadakan haknya.

Dengan masalah yang timbul tersebut, akhirnya pemerintah menepati janjinya untuk menjalankan adanya Agenda Reforma Agraria dengan menerbitkan Peraturan Presiden Nomor 86 Tahun 2018 tentang Reforma Agraria. Reforma Agraria dibutuhkan untuk mengatur kembali penguasaan, pemilikan penggunaan dan pemanfaatan tanah serta penanganan sengketa dan konflik agraria sebagai instrumen untuk mewujudkan keadilan dan kesejahteraan rakyat. Sebagai instrumen legal, Perpres Reforma Agraria memuat norma untuk menata ulang struktur agraria yang memastikan petani penggarap, nelayan, dan kelompok masyarakat pra-sejahtera dapat mengakses tanah negara, perlindungan terhadap hak tanah, dan menerima manfaat penyelesaian konflik agraria.

Perpres ini menggunakan tiga strategi dalam pelaksanaan reforma agraria, yaitu, sertifikasi hak milik, redistribusi tanah negara dan mekanisme penyelesaian konflik agraria. Satu hal perlu jadi perhatian, Perpres Reforma Agraria belum tegas menempatkan posisi masyarakat adat beserta hak-haknya dalam kerangka reforma agraria, terlihat dari tak ada penyebutan masyarakat adat sebagai salah satu subyek reforma agraria.

Perpres Reforma Agraria hanya menyebutkan, subyek reforma agraria terdiri dari tiga kategori, yaitu perorangan, kelompok masyarakat dan badan hukum. Subyek perorangan berupa petani penggarap, nelayan dan kelompok pekerja formal/informal. Sedangkan kelompok masyarakat, adalah kelompok dengan hak kepemilikan bersama atas tanah. Terakhir, badan hukum adalah koperasi dan badan usaha milik desa.

Masyarakat adat tak tercantum sebagai subyek reforma agraria. Walaupun terdapat kategori kelompok masyarakat dengan hak kepemilikan bersama, namun kategori masyarakat itu tak merujuk pada masyarakat adat, karena definisi kelompok yang dimaksud bersifat artifisial (dibentuk atas kepentingan bersama), alih-alih sebagai kesatuan sosial masyarakat adat.

Ketidakjelasan posisi masyarakat adat sebagai subyek reforma agraria berimplikasi serius terhadap persoalan-persoalan agraria terkait masyarakat adat. Setidaknya terdapat dua persoalan, yaitu, pertama, secara paradigmatik, perpres ini mengabaikan ada persoalan agraria terkait masyarakat adat dari kerangka kebijakan reforma agraria. Kedua, pada tingkat operasional, perpres ini mengeluarkan persoalan agraria terkait masyarakat adat dari skema perlindungan hak tanah dan mekanisme penyelesaian konflik agraria yang disasar dari kerangka kebijakan reforma agraria. Selain itu, Perpres Reforma Agraria inkonsisten dengan rujukan hukum, yaitu Ketetapan MPR No. IX/2001 tentang Pembaruan Agraria dan Pengelolaan Sumber Daya Alam (TAP MPR IX/2001). Secara jelas, TAP MPR IX/2001 menjelaskan, Reforma Agraria sebagai usaha menata ulang struktur agraria yang berkeadilan dengan memastikan hak masyarakat adat. Artinya, persoalan ketidakadilan dan ketidakpastian hak masyarakat adat masuk dalam ruang lingkup reforma agraria.

Dalam menjalankan reforma agraria secara menyeluruh, pemerintah tidak cukup hanya dengan melakukan redistribusi dan legalisasi aset pertanahan melainkan pemerintah juga harus segera melakukan penyelesaian sengketa pertanahan dan konflik yang terjadi hingga saat ini yang mana terjadi tumpang tindih dari struktur penguasaan, penggunaan, kepemilikan dan pemanfaatan sumber daya agraria karena lahirnya kebijakan dalam pengelolaan sumber daya agraria yang tidak mencerminkan prinsip keadilan dan kesejahteraan sehingga menimbulkan konflik dan sengketa agraria. 
Dalam Peraturan Presiden tentang reforma agraria yang mengatur tentang penyelesaian pertanahan dalam Bab IV mengenai penanganan sengketa dan konflik agraria, pemerintah membentuk gugus tugas reforma agraria secara bertahap, tetapi ketentuan ini hanya mengatur mengenai pihak yang terlibat di dalam penyelesaian sengketa atau konflik dan melimpahkan pengaturan yang lebih lanjut kepada Menteri. Tidak ada jaminan apapun terhadap hak masyarakat hukum adat sebagai bagian dari Warga Negara Indonesia. ${ }^{3}$

Dalam kaitannya dengan penataan aset di dalam legalisasi sertifikat objek atas tanah reforma agraria, tentu saja hal ini membuat suasana semakin rumit karena penyelesaian sengketa dan konflik agraria sebagai tujuan dibuatnya reforma agraria belum terpenuhi, maka diperlukan juga penegasan yang menekankan mengenai pengakuan terhadap eksistensi hak ulayat secara jelas dalam peraturan perundang-undangan yang dapat dijadikan dasar yang adil untuk menyelesaikan permasalahan yang ada.

Di dalam Ketetapan Majelis Pemusyawaratan Rakyat Republik Indonesia No. IX/MPR/2001 disebutkan bahwa masyarakat hukum adat harus diakui dalam prinsipprinsip Reforma Agraria, sedangkan dalam Peraturan Presiden No. 86 tahun 2018 tidak menyebutkan masyarakat adat sebagai subjek Reforma Agraria. Hal ini tentu akan menimbulkan konflik agraria baru seakan-akan masyarakat hukum adat sudah tidak diakui lagi eksistensinya di Indonesia. Program pembagian sertifikat saja tentu belum cukup efektif untuk dapat dikatakan sebagai reforma agraria, tetapi juga harus diimbangi dengan pembagian atau redistribusi tanah dan penyediaan akses bagi masyarakat khususnya subyek reforma agraria berupa penyediaan sarana prasarana berupa infrastruktur, pendampingan, pasar, permodalan, teknologi dan lain-lain, dengan harapan masyarakat sebagai subyek reforma agraria tersebut dapat meningkatkan kapasitasnya sehingga manfaat dari program pemerintah berupa reforma agraria yang terdiri dari penataan aset dan pemberian akses dapat benar-benar dirasakan oleh masyarakat.

Berdasarkan pada latar belakang di atas, tulisan ini akan menganalisis mengenai apakah legalisasi aset reforma agraria sudah memenuhi persyaratan pemilikan dan/atau penguasaan fisik tanah bagi masyarakat hukum adat marga di Kabupaten Maluku Tenggara ? Sehingga tulisan ini nantinya dapat dapat memberikan kejelasan legalisasi terhadap tanah masyarakat hukum adat marga sekaligus hak komunal masyarakat hukum adat marga terkait dengan terbitnya Peraturan Presiden Nomor 86 tahun 2018 yang tidak tegas dalam menyatakan kedudukan masyarakat adat sebagai subjek kebijakan penataan aset Reforma Agraria, agar hak-hak yang dimiliki oleh masyarakat hukum adat marga dapat diperjuangkan.

\section{B. METODE PENELITIAN}

Metode pendekatan yang digunakan dalam penelitian ini adalah Yuridis Empiris yang bersifat kajian deskriptif analisis kualitatif. Penelitian ini berusaha untuk menggambarkan akibat hukum terhadap Status Kepemilikan Hak Atas Tanah Adat Marga Dalam Kebijakan Penataan Aset Reforma Agraria Di Kabupaten Maluku Tenggara, pada penerbitan sertifikat kepada warga masyarakat adat Marga di Ohoi Debut, Ohoi Lilir, dan Ohoi Selayar. Teknik pengumpulan data yang digunakan dalam penelitian ini yaitu: Wawancara, kuesioner dan studi kepustakaan.

3 Sibuea, Harris Y.P. (2019), 'Urgensi Pembentukkan Rancangan Undang-Undang Tentang Masyarakat Hukum Adat', Info Singkat, Vol.XI, No. 04, h. 1.

102 |S A S I Vo1. $26 \mathrm{No} .1$, Januari- Maret 2020 


\section{PEMBAHASAN}

Pada dasarnya pengertian Legalisasi Aset adalah proses dari administrasi pertanahan yang meliputi ajudikasi, yakni dalam pengumpulan data fisik, data yuridis serta penetapan dan atau penerbitan surat keputusan pemberian hak atas tanah. Dimana tanah milik yang sudah bersertifikat maka akan dimanfaatkan sebagai sumber mata pencaharian bagi masyarakat terutama untuk modal usaha, sehingga kontribusinya nyata dalam peningkatan kesejahteraan masyarakat. ${ }^{4}$ Percepatan legalisasi aset/tanah merupakan sebuah keharusan untuk mewujudkan arah pembangunan nasional di bidang Pertanahan. Legalisasi aset dapat bertujuan sebagai penguatan keamanan tenurial dan kesejahteraan dari pemegang hak yang justru dapat memfasilitasi proses pelepasan atas tanah, jika tanpa didahului kebijakan redistribusi yang bertujuan menata kembali diferensiasi agraris. Legalisasi aset berfungsi ganda, maksudnya di satu sisi diperlukan untuk inklusi atau menjamin kepastian secara legal hak atas tanah bagi pemegangnya, namun di sisi lain memiliki arti eksklusi atau membatasi pihak lain berkesempatan mengakses atas tanah itu. Legalisasi aset untuk tujuan pasar tanah dan di atas wilayah yang didefinisikan sebagai tanah negara yang berakibat membatasi hak masyarakat guna mengaksesnya akan mendorong transisi agraris kapitalistik.

Legalisasi aset juga menguatkan klaim atas tanah dan pemusatan tanah pada segelintir orang atau negara, ketika pemerintah melakukannya tanpa mempertimbangkan kebijakan redistribusi yang bertujuan menata kembali diferensiasi agraris yang ada. Dengan kata lain, Legalisasi Aset tanpa Land Reform yang berciri redistributif, hanya akan memberi pelayanan pada mereka "yang memiliki tanah" dan bukan pada mereka "yang tidak memiliki tanah". Dalam perspektif lebih luas, jika struktur ekonomi suatu negara tidak kondusif bagi ekonomi masyarakat biasa yang memiliki sedikit tanah, maka sertifikat yang dimilikinya akan cenderung mudah terlepas dengan dijadikannya agunan kredit tatkala mereka membutuhkan 'dana segar' guna memenuhi kebutuhan hidupnya. Legalisasi aset juga mendorong proses transisi agraria. Pendaftaran tanah berupa pengukuran-perpetaan, pendaftaran hak atas tanah, yang berujung pada penerbitan surat tanda bukti hak adalah proses-proses legalisasi aset tanah. Semua ini bertujuan untuk "menjamin adanya kepastian hukum", sebagaimana tertuang dalam pasal 19 ayat (1) UUPA. Selain memberikan hak legal atas properti, setiap subyek hak dapat lebih mendapatkan perlindungan hukum atas obyek hak karena dilegalkan oleh pemerintah. Sertifikat memberikan keleluasaan gerak bagi subyek hak untuk mengalihkannya ke pihak lain.

Menurut pandangan Hernando De Soto ${ }^{5}$, legalisasi aset dapat mempercepat dan memperluas pasar tanah. Keberadaan sertifikasi tanah sejak awal sebenarnya ditempatkan sebagai instrumen yang menjalankan agenda utama berupa pelaksanaan UUPA dan land reform. UUPA sendiri memiliki lima misi utama: (1) perombakan hukum agraria, (2) pelaksanaan land reform, (3) penataan penggunaan tanah, (4) likuidasi hak-hak asing dalam bidang agraria, (5) penghapusan sisa-sisa feodal dalam bidang agraria. Sertifikasi hanyalah proses lanjutan dari pelaksanaan land reform tatkala ketimpangan tanah diperbaiki melalui redistribusi, dengan mencabut kepemilikan lama, dalam hal legalisasi aset tanah dan reforma agraria, kajian mutakhir menunjukkan bahwa tidak terbukti klaimklaim sertifikat sebagai aset modal bagi orang miskin, untuk diberikan tanahnya kepada

${ }^{4}$ Luthfi, Ahmad Nashih. (2013), 'Legalisasi Asset Dan Dampaknya Terhadap Akses Masyarakat Sekitar', Jurnal Bhumi, Vol. 03, No. 01, h. 15.

5 de Soto, Hernando. (2002), 'Listening To The Barking Dogs: Property Law Against Poverty In The Non-West1', Focaal-European Journal of Anthropology, No.41 h. 182 
pemilik baru beserta segenap bukti haknya (sertifikat). Legalisasi aset (sertifikasi) adalah tahap lanjutan dari redistribusi (land reform) untuk menciptakan hak baru, bukan ajudikasi atas tanah-tanah milik yang memang sudah dikuasai dan dibuktikan dalam kepemilikan adat. Program sertifikasi tidak dimaksudkan terlepas dari agenda utama ini. Transisi agraria untuk memahami kaitan antara legalisasi aset dan transisi agraria diuraikan terlebih dahulu beberapa pengertian berikut. Transisi agraria dimaknai sebagai perubahan sosial-ekonomi masyarakat pedesaan berbasis tanah.

Penerbitan sertifikat hak komunal dalam konteks reforma agraria merupakan sebuah terobosan hukum yang dilakukan Badan Pertanahan Nasional untuk melakukan perombakan mengenai pemilikan dan penguasaan tanah serta hubungan-hubungan hukum yang bersangkutan dengan penguasaan tanah.

Fungsi penataan penguasaan tanah meliputi tugas mengawasi pembatasan penguasaan pemilikan dan penggunaan tanah untuk melaksanakan proses dalam Pasal 6 (fungsi sosial hak atas tanah), Pasal 7 (asas bahwa pemilikan/penguasaan atas tanah tidak tak terbatas), Pasal 10 (asas bahwa setiap pemilik tanah harus menggarap/mengusahakan sendiri tanahnya) dan Pasal 1 (asas bahwa pemerintah mempunyai wewenang untuk mengambil alih dan menguasai tanah yang melebihi batas maksimum pemilikan serta membagikannya kepada yang memerlukan). ${ }^{6}$

Dapat kita lihat dalam Peraturan Menteri Agraria Dan Tata Ruang / Kepala Badan Pertanahan Nasional Republik Indonesia No. 10 Tahun 2016 Tentang Tata Cara Penetapan Hak komunal Atas Tanah Masyarakat Hukum Adat Dan Masyarakat Yang Berada Dalam Kawasan Tertentu yang Menyatakan bahwa definisi hak komunal dalam ketentual Pasal 1 ayat (1) adalah hak milik bersama atas tanah suatu masyarakat hukum adat,atau hak milik bersama atas tanah yang diberikan kepada masyarakat yang berada dikawasan tertentu.Dalam pasal 2 dan 3 disebutkan bahwa pemberian hak atas tanah komunal yang diperuntukan oleh masyarakat hukum adat dan masyarakat yang berada dalam suatu kawasan tertentu. Pengakuan hak tersebut tedapat dalam Pasal 33 Ayat (1) UUD 1945; Pasal 18b (2) UUD 1945; Pasal 2 (4) UUPA, tetapi dalam pasal 16 ayat 1 huruf( h) dimana jenis hak tanah tidak dicantumkan, dalam ketentuan Permen Agraria, disebutkan bahwa hak komunal berdasarkan sifatnya dapat dilakukan pendaftaran haknya. Adapun alur pendaftaran hak komunal berdasarkan Peraturan Menteri Agraria dan Tata Ruang/Kepala BPN Nomor 10 tahun 2016 dapat digambarkan sebagai berikut:

Tabel. 1

Alur Pendaftaran Tanah Komunial

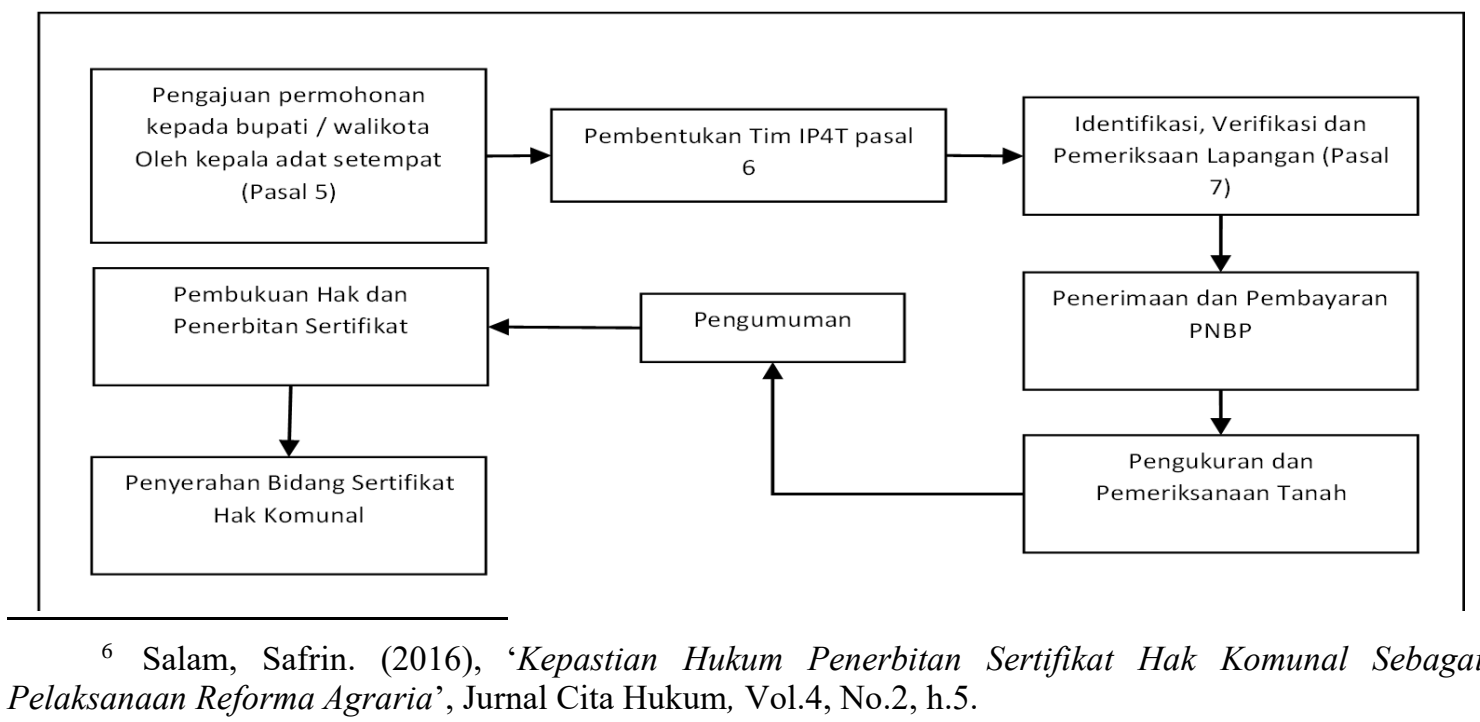

104 |S A S I Vo1. 26 No.1, Januari- Maret 2020 
Pemberian sertifikat hak komunal atas nama anggota masyarakat adat marga membawa implikasi hukum kepemilikan tanah komunal telah menjadi kepemilikan individu. Kepemilikan individu melalui Pasal 13 ayat (3) Perka BPN No. 10 tahun 2016 telah mengubah makna hak komunal yang dianggap sebagai hak ulayat yang bersifat hak publik. Melalui ketentuan tersebut, maka akibatnya hukum yang bersifat privat telah serta merta menghilangkan hakekat dari keberadaan hak ulayat yang telah diatur dalam UUPA sebagai undang-undang induk yang mengatur mengenai hak ulayat. Pemberian sertifikat kepada masyarakat hukum adat ini menurut Maruarar Siahaan ${ }^{7}$ dapat dijadikan dasar perlindungan hak ulayat masyarakat hukum adat, yakni dalam hal keikutsertaan masyarakat hukum adat untuk berkontribusi dalam investasi dan kegiatan yang ada melalui penyertaan saham dengan menghitung lahan masyarakat hukum adat yang digunakan dalam investasi oleh pengusaha dengan nilai keekonomisan yang wajar.

Konsep yang disebutkan dalam Perka BPN Nomor 10 tahun 2016 ini menggantikan peraturan yang ada sebelumnya yaitu Perka BPN No. 9 Tahun 2015. Dari rumusan Perka BPN Nomor 10 tahun 2016 tersebut, nampak bahwa konsep hak komunal itu berbeda dengan konsep hak ulayat yang diakui berdasarkan Pasal 3 UUPA. Perbedaan tersebut dapat dilihat dari dua hal, yakni perbedaan subyek hak dan perbedaan karakter hak. Subyek hak komunal tidak hanya kesatuan masyarakat hukum adat, melainkan meliputi pula masyarakat yang berada dalam kawasan tertentu. Perbedaan kedua, hak ulayat berdimensi publik sekaligus privat, sedangkan hak komunal lebih berdimensi privat (perdata). Hak ulayat tidak dapat dikategorikan sebagai hak atas tanah sebagaimana dimaksudkan dalam Pasal 4 jo Pasal 16 UUPA, sebaliknya hak komunal dapat dimaknai sebagai hak milik atas tanah yang dapat diterbitkan sertifikatnya.

Pengaturan Hak Komunal atas tanah melalui Peraturan Kepala BPN No. 10 tahun 2016 tidak memiliki landasan hukum dalam UUPA, tetapi dengan menggunakan penafsiran sistematik, landasan yuridis hak komunal atas tanah dapat ditemukan dalam UUPA. Sebagaimana diketahui, Pasal 2 UUPA menentukan bahwa tanah pada tingkatan tertinggi dikuasai oleh negara dan atas dasar hak menguasai itu Negara mempunyai wewenang mengatur hubungan-hubungan hukum antara orang-orang dengan tanah. Kemudian, dalam Pasal 4 ayat (1) dinyatakan bahwa atas dasar hak menguasai dari Negara ditentukan adanya macam-macam hak atas tanah yang dapat diberikan kepada dan dipunyai orang-orang baik sendiri maupun bersama-sama dengan orang- orang lain serta badan-badan hukum. Berdasarkan pasal 16 ayat (1) hak-hak yang dimaksudkan dalam Pasal 4 ayat (1) di antaranya adalah hak milik. Dengan demikian, hak komunal adalah hak milik yang diberikan kepada masyarakat hukum adat dan dipunyai orang secara bersama-sama dengan orang lain atau badan hukum. ${ }^{8}$

Pelaksanaan reforma agraria dimulai dengan adanya penyelesaian konflik agraria. Jika tidak dilaksanakan maka reforma agraria akan menimbulkan konflik baru, setelah penyelesaian sengketa dan konflik agraria, kemudian baru ditetapkan penataan aset yang terkait dengan legalisasi tanah reforma agraria. Prioritas kebijakan yang diarahkan kepada upaya untuk memacu sektor-sektor pembangunan yang mendorong tingkat pertumbuhan ekonomi tinggi yang tidak didasari dengan pemetaan tanah, ternyata akan menimbulkan masalah. Pelaksanaan reforma agraria di Indonesia diarahkan untuk melakukan

7 Siahaan, Maruarar. (2018), 'Pengakuan Dan Perlindungan Hak Ulayat: Aspek Penting Pembangunan Indonesia Menuju Sebesar-Besar Kemakmuran Rakyat, Jurnal Ketatanegaraan, Vol. 009, Juni, h. 107

8 Sudantra, I Ketut. (2018), 'Implikasi Keputusan Menteri ATR/Kepala BPN Nomor 276/Kep19.2/X/2017 Terhadap Kedudukan Tanah Milik Desa Pakraman', Udayana Master Law Journal, Vol.7. No.4, h. 557.

105 |S A S I Vo1.26 No.1, Januari- Maret 2020 
perubahan struktur penguasaan, pemilikan, penggunaan dan pemanfaatan tanah yang menjamin terwujudnya keadilan dan kepastian hukum dalam penguasaan, pemilikan, penggunaan dan pemanfaatan tanah Reforma Agraria harus dilakukan secara utuh dengan melakukan penataan ulang struktur agraria terlebih dahulu melalui pendataan pertanahan dan pengaturan ulang pemanfaatan tanah. Hal utama dari pelaksanaan Reforma Agraria di Indonesia saat ini adalah penyelesaian sengketa pertanahan yang dari tahun ke tahun terus bertambah tanpa penyelesaian secara signifikan.

Reforma Agraria ${ }^{9}$ adalah proses restrukturisasi atau penataan ulang susunan kepemilikan, penguasaan, dan penggunaan sumber-sumber agraria, khususnya tanah. Pasal 2 TAP MPR No. IX/MPR/2001 menyebutkan bahwa "Pembaruan agraria mencakup suatu proses yang berkesinambungan berkenaan dengan penataan kembali penguasaan, pemilikan, penggunaan, dan pemanfaatan sumber daya agraria, dilaksanakan dalam rangka tercapainya kepastian dan perlindungan hukum serta keadilan dan kemakmuran bagi seluruh rakyat Indonesia". Tujuan Reforma Agraria dalam TAP MPR No. IX/MPR/2001 antara lain untuk mengurangi kemiskinan; memperbaiki akses masyarakat kepada sumber-sumber ekonomi, terutama tanah; menata ulang ketimpangan penguasaan pemilikan, penggunaan, pemanfaatan tanah, dan sumber-sumber agraria; dan mengurangi sengketa dan konflik pertanahan dan keagrariaan. Secara faktual, ketimpangan struktur penguasaan, pemilikan, penggunaan, dan pemanfaatan sumber daya agraria salah satunya disebabkan oleh lahirnya kebijakan pengelolaan sumber daya agraria yang tidak mengindahkan prinsip keadilan dan kesejahteraan rakyat, sehingga memicu timbulnya sengketa dan konflik agraria.

Reforma agraria merupakan jawaban atas keinginan pendiri negara ini bahwa 'tanah adalah untuk kemakmuran rakyat'. Sebab, penguasaan tanah oleh segelintir kelompok di Indonesia mengakibatkan munculnya ketidakadilan sosial di dalam masyarakat. Dengan adanya reforma agraria, maka undang-undang sektoral juga perlu diselaraskan agar tidak terjadi tumpang tindih dalam kewenangan dan penanganannya. ${ }^{10}$

Untuk melaksanakan Reforma Agraria secara menyeluruh, pemerintah tidak cukup hanya dengan melakukan redistribusi dan legalisasi aset pertanahan. Namun, pemerintah juga perlu segera melakukan penyelesaian konflik dan sengketa pertanahan. Di sisi lain, untuk dapat menyelesaikan sengketa pertanahan, diperlukan data administrasi pertanahan lengkap, pembenahan kelembagaan, serta regulasi yang memadai.

Lahirnya UUPA dimaksudkan juga untuk mengakhiri dualisme hukum dalam masalah agraria yang sekaligus mewajibkan hukum adat lokal untuk tunduk pada kesatuan hukum nasional. Kepemilikan tanah komunal di desa-desa juga diakhiri dengan undang-undang atau peraturan-peraturan yang mengikutinya. akibatnya, tanah-tanah desa yang sebelumnya merupakan hak komunal berubah menjadi tanah milik yang dimiliki oleh petani-petani secara individual.

Reforma agraria sebagai suatu konsep struktur agraria yang di dalamnya terdapat usulan tentang perombakan dan penggunaan tanah dengan tujuan untuk mencapai masyarakat adil dan makmur, meningkatkan taraf hidup petani penggarap dan masyarakat pada umumnya, serta untuk memperkuat dan memperluas kepemilikan tanah bagi seluruh rakyat indonesia, terutama kaum petani. Dalam perjalanan waktu, inplementasi reforma agraria sebagai suatu konsep tersebut, di zaman sekarang, menuntut kembali lembaga

${ }^{9}$ Rongiyati, Sulasi. (2018), 'Reforma Agraria Melalui Perpres Nomor 86 Tahun 2018', Info Singkat, Vol X, No.19, h. 2.

10 Aziz, Djamal. (2018), 'Tanah Untuk Kemakmuran Rakyat, Reforma Agraria Sebuah Keniscayaan', Jurnal Ketatanegaraan, Vol. 009, Juni, h. 183-184

106 |S A S I Vo1. 26 No.1, Januari- Maret 2020 
komunal atas tanah-tanah desa yang di awal berlakunya reforma agraria dengan undangundang menjadikan keberadaan tanah desa dengan hak komunal berubah menjadi tanah milik yang dimiliki secara individu.

Kebijakan pemerintah untuk kembali dan memenuhi tuntutan rakyat khususnya masyarakat hukum adat dan kelompok masyarakat yang berada dalam suatu kawasan tertentu, dengan dikeluarkannya Perka BPN No. 10 Tahun 2016, jelas terlihat kemauan dan tekad pemerintah untuk memberi perlindungan dan kepastian hukum bagi masyarakat hukum adat dengan diberi peluang sebagai subjek pemegang hak atas tanah dengan hak komunal. Reforma agraria adalah basis pembangunan progresif yang berdasarkan prinsip bahwa tanah sebagai alat produksi tidak boleh dijadikan sebagai alat pemerasan. Pembangunan yang adil atas sumber-sumber penghidupan rakyat dimaksudkan untuk merombak struktur pertanahan guna merealisasikan keadilan sosial.

Di dalam kerangka peningkatan kesejahteraan rakyat dan menunjukkan keadilan sosial, maka reforma agraria menjadi pijakan kebijakan yang penting dalam kepastian hukum mengenai kepemilikan tanah untuk para petani. Demikian khususnya kepada masyarakat hukum adat dengan di daftarkannya hak-hak komunal pada instansi pendaftaran tanah atau kantor pendaftaran tanah, maka akan meningkatkan produktivitas hasil pertanahan. Jadi sesungguhnya patut kita pahami bahwa reforma agraria itu mencakup semua sumber-sumber agraria (perkebunan, kehutanan, pertambangan dan lain-lain), termasuk hak-hak komunal bagi masyarakat hukum adat.

Sistem pendaftaran tanah di BPN belum dapat diandalkan untuk pendaftaran tanah wilayah adat. Secara praktiknya, BPN hanya dapat melakukan pendaftaran tanah adat jika tanah itu sudah dikeluarkan dari kawasan hutan negara, hal ini mensyaratkan terlebih dahulu untuk diformalkan sebagai subek hukum pemegang hak atas tanah wilayah adat. Wilayah adat pun juga harus diformalkan sebagai satu jenis bidang tanah yang dapat dilekati hak oleh suatu masyarakat hukum. ${ }^{11}$ Hal ini harus di realisasikan dengan mendaftar dan mengakui kepemilikan kolektif wilayah-wilayah adat di Indonesia. Jangan sampai diterbitkannya peraturan presiden reforma agraria ini hanya sebagai kewenangan legal pejabat publik untuk memberi lisensi kepada perusahaan untuk mengambil serta mengeksploitasi sumber daya alam, karena hal ini akan dirasa masyarakat hukum adat sebagai perampasan tanah, penggusuran tempat tinggal maupun penyempitan ruang kelola masyarakat hukum adat. Subjek dan obyek reforma agraria ini berpotensi salah sasaran.

Melalui Pendaftaran Tanah Sistematis Lengkap (PTSL), Kementerian ATR/BPN menargetkan 126 juta bidang tanah bersertifikat di seluruh wilayah Indonesia tahun 2025. Kebijakan yang telah dikeluarkan oleh pemerintah perlu dilakukan pengkajian dalam tataran implementasinya di setiap Pemerintah Daerah. Oleh karena itu, penelitian ini mencoba memberikan gambaran terkait upaya Pemerintah Daerah untuk merespon kebijakan pertanahan saat ini dengan mengambil lokasi penelitian di Kantor Pertanahan Kabupaten Maluku Tenggara,ohoililir, ohoidebut dan ohoiselayar.

Kebijakan Pertanahan yang digunakan oleh Kantor pertanahan Kabupaten Maluku Tenggara saat ini merujuk kepada Peraturan Menteri Agraria dan Tata Ruang/Kepala Badan Pertanahan Nasional Nomor 12 Tahun 2017 tentang Percepatan Pendaftaran Tanah Sistematis Lengkap. Dalam proses berjalannya program, petugas pertanahan Kabupaten

11 Rachman, Noer Fauzi. (2014), 'Masyarakat Hukum Adat Adalah Penyandang Hak, Subek Hukum, Dan Pemilik Wilayah Adatnya', Wacana Jurnal Transformasi Sosial, Vol.14, No.33, h. 42. 
ohoidebut dan ohoililir tidak sedikit kerap kali mendapat hambatan yang dapat mengganggu efektivitasnya.

Penggusuran dan penghilangan desa di Indonesia dari tahun ke tahun telah berada pada level yang mengkhawatirkan dan terancam hilang dalam pusaran pembangunan insfrastruktur serta perluasan perkebunan, jangan sampai wilayah adat diklaim secara sepihak oleh pihak lain dan menimbulkan konflik. Tak cukup hanya peraturan yang telah diterbitkan, tanpa pelaksanaannya di lapangan sesungguhnya sama dengan ketiadaan peraturan itu sendiri. Perka BPN No. 10 tahun 2016 menjadi salah satu regulasi yang dianggap dapat mendukung pelaksanaan reforma agraria dari sisi pemilikan dan/atau pengusahaan secara komunal Namun sayangnya di tahun Permen ini minim realisasi.

Kementerian ATR/BPN belum menemukan bentuk ideal dari sertifikasi secara komunal. Dalam hasil penelitian Kementerian ATR/BPN dan Pusat Studi Agraria IPB (2017) tentang Pendaftaran Tanah Hak Komunal ditemukan beberapa aspek penting yang harus diperhatikan dalam pelaksanaan hak komunal, pertama bentuk pemilikan / penguasaan tanah, kewenangan pengaturan atas tanah dan mekanisme legalisasi. ${ }^{12}$ Secara hukum, pengakuan (hak) mensyaratkan pengenalan tentang subjek, objek dan jenis hak yang diakui itu sendiri, contohnya sertifikat atas sebidang tanah harus ada kejelasan siapa subjek hukumnya, tanpa ada kejelasan maka pengakuan secara hukum tidak akan efektif serta pengembalian hak-hak masyarakat adat yang bersangkutan. ${ }^{13}$

Dampak yang dapat ditimbulkan apabila tidak ada kejelasan dalam Peraturan Presiden Nomor 86 Tahun 2018 terhadap masyarakat hukum adat yaitu: (a) tergusurnya rakyat dari tanah-tanah dan desa mereka. Hal ini secara langsung menghilangkan hak atas tanah, mata pencaharian dan wilayah hidup yang berakibat hilangnya kehidupan sosial budaya masyarakat; (b) menyempitnya ruang hidup masyarakat hukum adat: (c) merosotnya kepercayaan masyarakat yang menjadi korban pemerintah; (d) meluasnya konflik agraria ke bentuk konflik lain, seperti konflik antar desa dan konflik antara penduduk asli dan pendatang.

Melemahnya eksistensi atau menghilangnya hak ulayat, diusahakan penampungannya dalam rangka pelaksanaan hak menguasai negara, yang mencakup menggantikan peran kepala adat dan para tetua atau masyarakat hukum adat marga yang bersangkutan, seperti halnya tanah-tanah di daerah lain khususnya adat marga di Kabupaten Maluku Tenggara.

Jadi pengakuan dalam reforma agraria terhadap masyarakat adat yang beragam adalah dengan cara menjamin masing-masing kebijakan tidak saling bertentangan satu sama lainnya, pengakuan masyarakat adat marga mungkin membutuhkan logika hukum yang berbeda tetapi bisa saja bagi suatu model pengakuan tersebut bersifat menyeluruh walau hanya bersifat deklaratif. Maka tetap pula diperlukan peraturan perundangundangan turunan maupun khusus yang membuat operatif.

\section{P E N U T U P}

Implementasi Reforma Agraria yang dituangkan dalam Peraturan Presiden No. 86 tahun 2018 belum optimal karena masyarakat hukum adat hanya disebutkan secara

12 Konsorsium Pembaharuan Agraria 2017, 'Reforma agraria di bawah bayangan investasi', Catatan Akhir Tahun 2017, h. 36.

13 Zakaria, Yando. (2016), 'Strategi Pengakuan Dan Perlindungan Hak-Hak Masyarakat (Hukum) Adat: Sebuah Pendekatan Sosio-Antropologis', Jurnal Bhumi, Vol.2 No.02, h. 135. 
eksplisit. Ketidakpastian hukum atas pengaturan masyarakat hukum adat. Tidak disebutkannya masyarakat komunal sebagai subyek pendaftaran hak atas tanah membuat permasalahan hukum yang berkepanjangan mengenai eksistensi masyarakat hukum adat yang sudah mulai tidak diakui lagi keberadaannya sehingga peraturan mengenai pendaftaran tanah yang berlaku pada saat ini belum memberikan keragaman di masyarakat hukum adat yang bersifat komunal. Di dalam Peraturan Presiden No. 24 tahun 1997 tentang pendaftaran tanah dan Peraturan Presiden No. 86 tahun 2018 belum mampu memecahkan persoalan tentang sertifikat-sertifikat tanah yang dimiliki masyarakat adat yang merupakan ciri khas dari subyek hak komunal. Lahirnya Perka BPN No. 10 tahun 2016 hanya sedikit menjawab tuntutan masyarakat adat sebagai subyek reforma agraria atas penguasaan tanah yang terjadi di Indonesia ini. Terbitnya sertifikat hak komunal yang diharapkan terjadi karena Perka BPN No. 10 tahun 2016 dapat memberikan kepastian hukum yang diberikan oleh Negara untuk masyarakat adat atas tanah komunal.

Amandemen terhadap UUPA telah diamanatkan dalam TAP MPR N0. IX/MPR/2001 tentang Pembaharuan Agraria dan Pengelolaan Sumber Daya Alam, serta Kepres Nomor 34 Tahun 2003 tentang Kebijaksanaan Nasional di bidang pertanahan, tetapi Reforma Agraria harus juga didasarkan pada kesadaran bahwa hukum nasional merupakan suatu sistem yang tidak hanya terdiri dari norma-norma hukum belaka tetapi juga mencakup seluruh lembaga dan organisasi, mekanisme, prosedur hukum, falsafah dan budaya hukum termasuk perilaku hukum pemerintah dan masyarakat. Pemberlakuan Perka BPN No. 10 Tahun 2016 memiliki implikasi redistribusi pendapatan kepada masyarakat hukum adat dan kelompok masyarakat yang berada dalam suatu kawasan tertentu. Redistribusi aset tanah memungkinkan masyarakat hukum adat dan kelompok masyarakat yang berada dalam suatu kawasan tertentu memperoleh akses informasi yang lebih besar sekaligus peluang investasi di bidang produksi yang baru.

Manakala Perka BPN No. 10 Tahun 2016 ditetapkan dan dilaksanakan dengan baik, maka peran Reforma Agraria dalam pembangunan tidak hanya tercermin dalam perbaikan efektivitas, kesejahteraan dan keadilan, tetapi juga membawa kekuatan politis pada masyarakat hukum adat dan kelompok masyarakat yang berada dalam suatu kawasan tertentu, harus mampu mendorong partisipasi rakyat yang lebih besar dalam penjabaran kebijakan publik yang berorientasi pembangunan.

Ke depan, harus ada bentuk legalisasi secara komunal yang pasti dan mengakomodir perbedaan tersebut. Meski sertifikasi hak komunal bukan jalan terbaik atau satu-satunya pilihan, namun dapat menjadi pilihan untuk menguatkan ikatan masyarakat, serikat tani setelah proses redistribusi. Semua usaha komunalisme atau kolektivisme tersebut harus dibarengi terus-menerus dengan penguatan organisasi rakyat, serikat petani dan organisasi masyarakat adat. Keduanya harus menjadi proses yang terintegrasi, bukan parsial.

\section{DAFTAR PUSTAKA}

\section{Buku}

[1] Hajati, Sri, dkk. (2018). Politik hukum pertanahan, Surabaya: Airlangga Univeritas Press.

[2] Sembiring, Rosnidar. (2017), Hukum pertanahan adat, Depok: Rajagrafindo Persada. 
[3] Sumardjono, Maria S.W. (2001), Kebijakan pertanahaan antara regulasi dan implementasi, Jakarta: Kompas.

\section{Jurnal dan Lain-Lain}

[4] Abdurrahman. (2015), Draft laporan pengkajian hukum tentang mekanisme pengakuan masyarakat hukum adat, Pusat Penelitian Dan Pengembangan Sistem Hukum Nasional Badan Pembinaan Hukum Nasional Kementrian Hukum Dan HAM RI'. Jakarta.

[1] Aziz, Djamal. (2018), Tanah untuk kemakmuran rakyat, reforma agraria sebuah keniscayaan, Jurnal Ketatanegaraan, Vol. 009, Juni.

[2] Budimanta, Arif. (2018), Mewujudkan Keadilan Sosial Melalui Reforma Agraria, Jurnal Ketatanegaraan, Vol. 009 Juni.

[3] Luthfi, Ahmad Nashih. (2013), Legalisasi Asset Dan Dampaknya Terhadap Akses Masyarakat Sekitar, Jurnal Bhumi, Vol. 03, No. 01.

[4] Rachbini, Didik J. dan Mattalata, Andi. (2018), Pertanahan Dalam Perspektif Teori Dan Konstitusi, Jurnal Ketatanegaraan, Vol. 009 Juni.

[5] Rachman, Noer Fauzi. (2014), Masyarakat Hukum Adat Adalah Penyandang Hak, Subek Hukum, Dan Pemilik Wilayah Adatnya, Wacana Jurnal Transformasi Sosial, Vol.14, No.33.

[6] Rongiyati, Sulasi. (2018) Reforma Agraria Melalui Perpres Nomor 86 Tahun 2018, Info Singkat, Vol X, No.19.

[7] Salam, Safrin. (2016), Kepastian Hukum Penerbitan Sertifikat Hak Komunal Sebagai Pelaksanaan Reforma Agraria, Jurnal Cita Hukum, Vol.4, No.2.

[8] Siahaan, Maruarar. (2018), Pengakuan dan perlindungan hak ulayat: aspek penting pembangunan Indonesia menuju sebesar-besar kemakmuran rakyat, Jurnal Ketatanegaraan, Vol. 009, Juni 2018.

[9] Sibuea, Harris Y.P. (2019), Urgensi Pembentukkan Rancangan Undang-Undang Tentang Masyarakat Hukum Adat, Info Singkat, Vol. XI, No. 04.

[10] Wicaksono, Aditya. \& Yudha Purbawa 2018, Hutang Negara Dalam Reforma Agraria Studi Implementasi Mandat 9 Juta Hektar Tanah Indonesia, Jurnal Bhumi, Vol. 04 No.1.

[11]Zakaria, Yando. (2016), Strategi Pengakuan Dan Perlindungan Hak-Hak Masyarakat (Hukum) Adat: Sebuah Pendekatan Sosio-Antropologis, Jurnal Bhumi, Vol.2 No.02.

[12] Zakie, Mukmin. (2016), Konflik Agraria Yang Tak Pernah Reda, Jurnal Legality, Vol.24, No.1.

[13] Devita, Irma. (2018), Reforma agraria, Info Kenotariatan,web diposting pada 4 desember 2018 dilihat pada tanggal 4 april 2019, https://www.google.co.id/amp/s/irmadevita.com/amp/2018/reforma-agraria.

[14] Konsorsium Pembaharuan Agraria 2017, Reforma agraria di bawah bayangan investasi, Catatan Akhir Tahun 2017. 